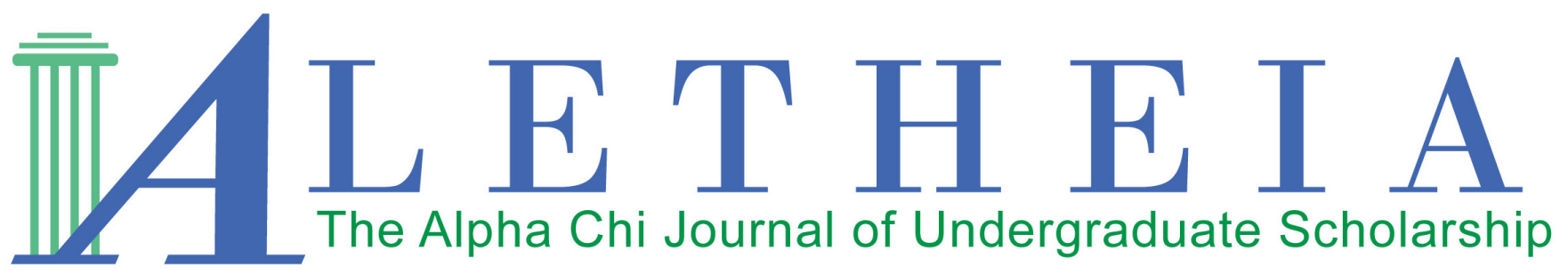

Volume 2 | Issue 2 | 2017

\title{
The Strongest Leader
}

\author{
Crystal Padilla
}

\author{
Lindenwood University \\ Missouri Pi Chapter
}

Vol. 2(2), 2017

Article Title: The Strongest Leader

DOI: $10.21081 / \mathrm{AX} 0150$

ISSN: $2381-800 \mathrm{X}$

Key Words: leadership, literary figures, adapt, management

This work is licensed under a Creative Commons Attribution 4.0 International License.

Author contact information is available from the Editor at editor@alphachihonor.org.

\section{Aletheia-The Alpha Chi Journal of Undergraduate Scholarship}

- This publication is an online, peer-reviewed, interdisciplinary undergraduate journal, whose mission is to promote high quality research and scholarship among undergraduates by showcasing exemplary work.

- Submissions can be in any basic or applied field of study, including the physical and life sciences, the social sciences, the humanities, education, engineering, and the arts.

- Publication in Aletheia will recognize students who excel academically and foster mentor/mentee relationships between faculty and students.

- In keeping with the strong tradition of student involvement in all levels of Alpha Chi, the journal will also provide a forum for students to become actively involved in the writing, peer review, and publication process.

- More information and instructions for authors is available under the publications tab at www.AlphaChiHonor.org. Questions to the editor may be directed to editor@alphachihonor.org.

\footnotetext{
Alpha Chi is a national college honor society that admits students from all academic disciplines, with membership limited to the top 10 percent of an institution's juniors, seniors, and graduate students. Invitation to membership comes only through an institutional chapter. A college seeking a chapter must grant baccalaureate degrees and be regionally accredited. Some 300 chapters, located in almost every state, induct approximately 12,000 members annually. Alpha Chi members have been "making scholarship effective for good" since 1922.
} 


\title{
The Strongest Leader
}

\author{
Crystal Padilla \\ Lindenwood University \\ Missouri Pi Chapter
}

\begin{abstract}
Businesses often search for a leader who is just the right fit. Businesses are entering an era in which their most valuable resources are no longer just capital or assets, but people. What should the ultimate leader do to drive not only the production the business needs, but also to mold its personnel? What should executives and recruiters be looking for when attempting to hire the best candidate? With so many different types of leaders to choose from, which choice is best? This paper explores five common leadership styles and classifies them under the heading of well-known literary figures, such as Beowulf and Mr. Darcy. This project outlines the assets and liabilities of each leadership style and how they match the literary figure. It then concludes by determining which of the literary figures' behaviors the best leaders exhibit.
\end{abstract}

Key words: leadership, literary figures, adapt, management

Whether it is in business, at school, on a sports team or a shopping trip, someone is always in charge. Age has no bearing; leadership qualities can be seen in a conference room full of employees, a classroom of toddlers, a football locker room, or with a group of teenagers out for the day. Parents are also leaders in a family; they are domestic CEOs that bear the weight of decisions regarding household management and finances. Historically, conquests have succeeded or failed based on who was leading the charge. Literature, too, provides examples of leaders who have succeeded or failed. Today, the business world is the most obvious place to look for leadership expertise. Leadership qualities are present in all areas, from entry-level positions through the executive level. While all businesses want the best type of leader, the question of which type of style is best is highly debatable. Leadership styles can be divided into five basic types: autocratic, charismatic, puppeteers, commanders, and micromanagers.
Autocratic bosses are absolute and will brook little argument from subordinates. Trust is the driving factor for these leaders, allowing a select few, if any, to be part of the decision-making process. Seeing the big picture and formulating strategies are natural strengths of this type of leader, as is making responsible decisions for the business. However, with little input accepted from the seemingly cold and uncaring figurehead, these tactics can cause feelings of resentment from subordinates. Mr. Darcy, the aristocratic landowner and overseer from Jane Austen's famed novel Pride and Prejudice, brings this leadership style to life. Upon being asked for her hand in marriage, Elizabeth Bennett tells Mr. Darcy that his manners indicate to her "the fullest belief of your arrogance, your conceit, and your selfish disdain of the feelings of others" (143). It is not until later in the novel that Ms. Bennett realizes what not everyone can see - the depth of emotion in Mr. Darcy. Like Miss Bennett, long-term employees could come to appreci- 
ate the honesty and success this management style provides and learn not to stress about the minutia of the decision-making process. Other staff, with little or no personal attachment to their position, can work well under this type of authority. Liabilities for this type of style can include complaints from employees who feel unappreciated, especially at first, and the possibility of stifling the upward momentum of mid-level management staff. As long as results are forthcoming, executive-level management should be pleased by this type of leader due to the positive business decisions they make and the hyper-professionalism they practice.

Charismatic management types possess a passion for whatever task is assigned and can excite those around them into a frenzy of energy. Famous literary figures like Arthur Conan Doyle's brilliant detective Sherlock Holmes and Louisa May Alcott's indomitably-spirited character Josephine March both possess these qualities. In Doyle's novel The Hounds of the Baskervilles, Mr. Holmes works to solve his case: "Sherlock Holmes struck his hand against his knee with an impatient gesture. 'If I had only been there!' he cried. 'It is evidently a case of extraordinary interest, and on which present immense opportunities to the scientific expert"" (646). Highly skilled and team-work oriented, charismatic leaders run full steam ahead into any obstacle. Problems are solved with creative thinking and execution; however, these leaders' temperament is a flaw when things do not go according to plan. For example, in Alcott's Little Women when Amy March burns Josephine March's manuscript, Jo is overcome with rage: "Amy got no further, for Jo's hot temper mastered her, and she shook Amy till her teeth chattered in her head, crying, in a passion of grief and anger" (70). In the business world, these high and low points can affect staff morale. Workers should initially be inspired by the passion that drives these leaders but can easily become exhausted by the rigorous pace. Many could quickly burn out due to the frequent emotional highs and lows. Upper management should seek these types of leaders when looking to fill roles that require fast-paced, creative problem-solving skills. Liabilities of this type can include a tendency to show their temper and a disrespect of policies that conflict with their overall vision. Employees who share a common goal and skill set with the leader, instead of being temporarily inspired, should do well under this type of leader.

The commander is another leadership style with a direct approach. Commanders are intelligent, militant, and strict, requiring high goals for management and subordinates alike. Loyalty is a factor on both sides of this equation: commanders inspire allegiance in their soldiers and in turn come to trust and depend on them. Leading by example, commanders are not afraid to get "down in the trenches" with the staff. Beowulf, the Geat soldier from the Anglo-Saxon poem of the same name, is an excellent example of this type of leadership. Coming to the aid of the Danes when the evil monster Grendel challenges the king's rule, Beowulf and his band of trusted soldiers defeat the monster Grendel. Beowulf also inspires soldiers not a part of his crew into admiration. For example, when Unferth learns that Grendel's mother is waiting to exact revenge and is too afraid to face her, he realizes that he is not Beowulf's equal. Instead, Unferth strives to join Beowulf's band:

Unferth had tried to forget his greeting to Beowulf, his drunken speech of welcome; a mighty warrior, he lent his weapon to a better one. Only Beowulf would risk his life in that lake; Unferth was afraid, gave up that chance to work wonder, win glory and a hero's fame. But Beowulf and fear were strangers; he stood ready to dive into battle (69).

Workers who can handle this strict authoritative approach should quickly join the ranks of a successful group; however, less assured staff can be easily intimidated by this style and resign. High turn-over rates may hinder a commander, but once a reliable core staff is obtained, nothing will slow a commander's progress. The commander's success should earn a company's continued support, but the success is dependent on the vision for the company remaining in line with the commander's. A commander's loyalty is to the crew and mission, not the company's executives.

The autocratic, charismatic and commander leadership styles are all very direct in approach. But many other leaders are not this straightforward and watch from a distance to see larger natural patterns first. They often gently push in different directions if needed. This handsoff approach is reminiscent of a puppeteer who gently holds the strings of the marionette that dances unaware of the guidance. Only self-motivated and confident workers do well under this influence; employees who need frequent assistance could become frustrated by the lack of direct support. Executives may also become disenchanted with this leader if they don't see immediate results. The puppeteer style of management can be seen in the character Albus Dumbledore from the Harry Potter series written by J. K. Rowling. Albus Dumble- 
dore is the old sage headmaster who directs the course of young Harry Potter's life. Harry Potter is given monumental tasks to complete with very little direction and no knowledge of the future. In the epic final book, Harry Potter must face the fact that Dumbledore did not give him the answers. Harry realizes he must proceed or quit and decides to "accept that he had not been told everything that he wanted to know, but simply to trust" (563). With the right type of employee, this style could inspire great success and results, while with other employees, it could lead to ultimate failure. The liability that goes with this style is its unpredictability.

Thus far, all of the leadership styles have been mostly positive, with each having some specific liabilities. However, an authority figure who is inexperienced or has confidence issues is a type of flawed leadership. The micromanager is an example of flawed governance. Nurse Ratched, from Ken Kesey's novel One Flew Over the Cuckoo's Nest, exercises complete control over the ward and the daily lives of the patients at a mental hospital — even the doctor bows to the tyrant's wishes. Randle Patrick McMurphy, a patient, wrestles with Nurse Ratched's rule. Unable to handle the stress that such control inspires, McMurphy rebels and causes chaos in the ward, leading to his eventual demise. Assets to this leadership style include detailed organization of procedures and acute attention to detail. While there are small pockets of companies or businesses in which this type of leader can be effective, the staff may easily take issue with this leader's unbending authority. Complications that need resolution could accumulate when only one person has the authority to make changes in procedure. Mid-level management growth might also come to a halt, since there is no chance to gain experience. Overall, this leadership style will usually fail because the risks outweigh the rewards.

Each type of leadership has its assets and liabilities, but the question remains, which of these is the best style of management? Some industries may look for a specific leadership style to fit a niche role; but more realistically, managers themselves can adapt and change their style of management based on the needs of a specific employee or situation. Perhaps combining the different qualities of each style will best serve a company: channeling Josephine March to inspire and drive passion in a flat environment, letting an Albus Dumbledore push an employee to discover self-confidence, bringing on a Nurse Ratched when a group is out of control, and al- lowing a Beowulf or Mr. Darcy to pull up production standards if the business is not performing. In the end, great leadership is all about understanding people. People do not come in one shape or size. Strong teams, in any workplace environment, depend on playing to individual gifts. Revision of the leader's style to develop strengths and minimize weaknesses will help develop proficient employees and ultimately benefit any business.

\section{Works Cited}

Alcott, Louisa May. Little Women. Whitman Publishing Company, 1951.

Austen, Jane. Pride and Prejudice. Barnes \& Noble Books, 1993.

Burton, Raffel, trans. Beowulf. Signet Classic, 1999.

Conan Doyle, Sir Arthur. The Greatest Adventures of Sherlock Holmes. Fall River Press, 2012.

Kesey, Ken. One Flew Over the Cuckoo's Nest. Penguin Books, 1976.

Rowling, J.K. Harry Potter and the Deathly Hallows. Scholastic Inc., 2007. 